キノコの保存に対する家庭用冷凍冷蔵庫の利用 一冷凍したマツタケ，ナメコと水戻しした干しシイタケを 冷凍保存した場合の受容性の検討一

\author{
石黒弥生* ·菅原龍幸** \\ (*銀座クッキング $\quad * *$ 女子栄養大学 $)$
}

\title{
Use of household refrigerator for mushroom storage - Comparison of acceptabillity of storing frozen Tricholoma matsutake and Pholiota nameko and rehydrated dried Lentinus edodes in household freezer-
}

\author{
Yayoi Ishikuro*, Tatsuyuki Sugahara** \\ *Ginza Cooking School, 2-8-2, Ginza, Chuo-ku Tokyo 104-0061 \\ **Kagawa Nutrition University, 4-46-14, Aoyama-bldg. Sengoku, Bunkyo-ku Tokyo 112-0011 \\ 干104-0061 東京都中央区銀座 2-8-2 \\ テ112-0011 東京都文京区千石 4-46-14 青山ビル 2 F
}

\begin{abstract}
A short-term frozen storage time has no effect on the taste of Tricholoma matsutake (abbrev. matsutake) in soup and foil-roast,and Pholiota nameko (nameko) in rice porridge. The taste of frozen matsutake and nameko have taste similar to the fresh ones in sensory tests.

A three-month frozen storage is utilized for dried shiitake which is rehydrated before freezing. The rehydrating method is for 8 to 12 hours at $5{ }^{\circ} \mathrm{C}$ in a household freezer.
\end{abstract}

はじめに

前報1)で, 市販されている各種のキノコを家庭用冷蔵 庫で冷凍したものと生鮮のままのものを加熱し, キノコ 類の主要な呈味成分である $5^{\prime}-\mathrm{GMP}$ を両者の間で比 較した。加熱による呈味成分生成量は, 生鮮のままのも のを加熱したものより，冷凍してから加熱したもののほ うが多いことを見出した。また, 冷凍キノコと生鮮のま まのものを用いてキノコ飯を作り，その官能的な受容性 について比較した。その結果，シイタケとブナシメジは， 冷凍したものが旨味などの官能的受容性が高い結果を得 た。その他のキノコ類においては, 冷凍品と生鮮品との 間に違いは見られないこと, 嗜好性は低下しないことを 報告した。

今回は, 前回の実験に引き続き, ナメコとマツタケに ついて，また，一方では，干しシイタケを水戻ししたも のを冷凍保存し，これを調理したものについて官能検査
を行った。

干しシイタケについては, 調理ごとに行う水戻しが煩 わしいとの意見が一部において根強くあること，さらに， 干しシイタケを水戻しする際, 一度にまとめて行い, こ れを冷凍保存しておけば, 調理の度に水戻しする煩わし さの軽減と水戻し時間の省力化に繋がると考えて行い検 討した。以下にその結果を報告する。

\section{実験方法}

(1) 試料

マツタケ (Tricholoma matsutake), ナメコ (Pholiota nameko）はいずれも東京の築地市場で購入した。なお， マツタケは中国産である。

干しシイタケ (Lentinus edodes dried) は平成18年度 産春子の上冬菇（静岡産）上上香信（宮城県産）を用い た。いずれも日本特用林産振興会から提供されたもので ある。 
表 1 調理方法

\begin{tabular}{|c|c|c|}
\hline マツタケのホイル焼き & マツタケ汁 & ナメコ雑炊 \\
\hline $\begin{array}{l}\text { マツタケ } \\
\text { 薄口奨油 }\end{array}$ & $\begin{array}{l}\text { マツタケ } \\
\text { 水 } \\
\text { 塩 }\end{array}$ & $\begin{array}{l}\text { ナメコ } \\
\text { 飯 } \\
\text { 水 } \\
\text { 塩 }\end{array}$ \\
\hline $\begin{array}{l}\text { 手で } 8 \text { 等分に裂いたマツタ } \\
\text { ケに薄口奨油をふらかけ, } \\
\text { ホイルに包み, あらかじめ } \\
180^{\circ} \mathrm{C} \text { 熱しておいたオー } \\
\text { ブンで10分間焼いた。 }\end{array}$ & 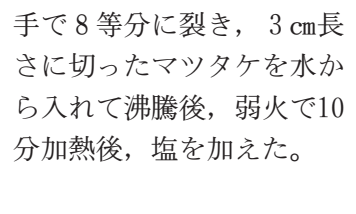 & $\begin{array}{l}\text { 飯はザルに入れて水洗いし, } \\
\text { 水·塩・ナメコを加え沸騰 } \\
\text { 後弱にして10分間加熱し } \\
\text { た。 }\end{array}$ \\
\hline
\end{tabular}

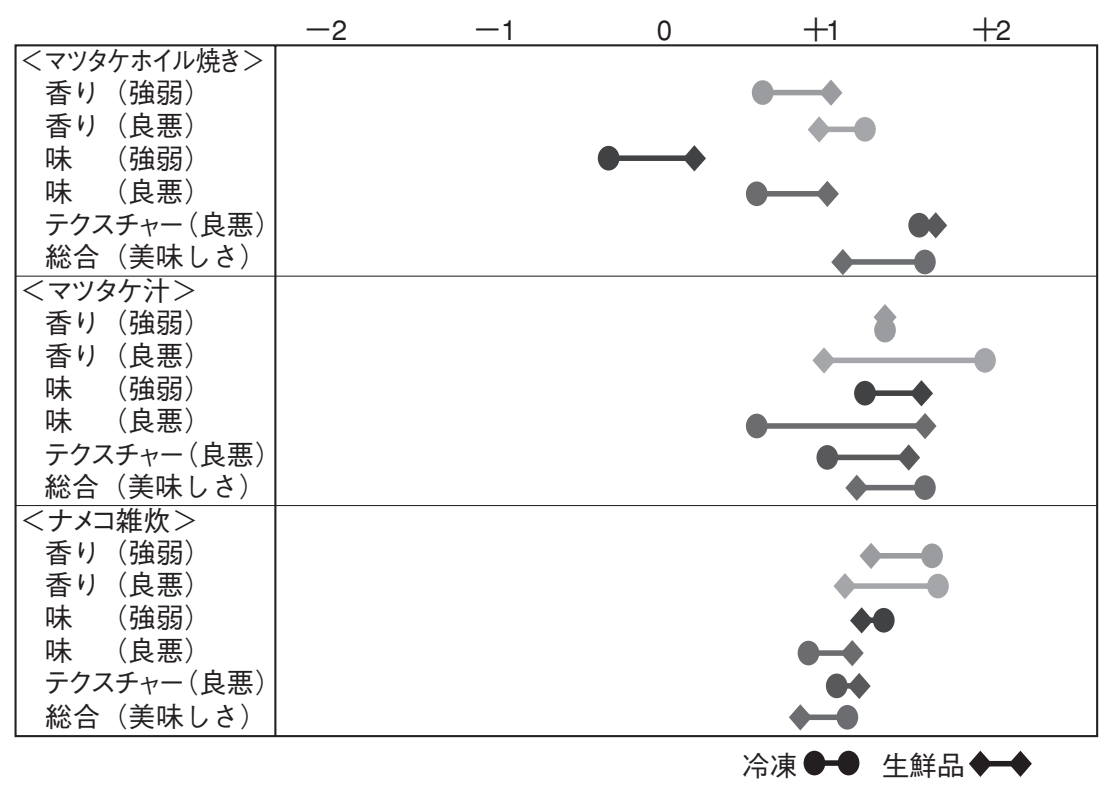

図 1 生鮮品と冷凍したキノコを調理した官能検査結果

\section{（2）冷凍方法}

マツタケ，ナメコは家庭用冷蔵庫の冷凍庫内 $-15{ }^{\circ} \mathrm{C}$ で 16〜24時間緩慢凍結して使用した。対照は購入翌日に使 用した。

干しシイタケは， 2 分割して半分は対照として調理 · 官能検査に用いるまで冷蔵庫内 $1 \sim 5{ }^{\circ} \mathrm{C}$ で保存した。他 の半分は 20 倍量の水を用いて冷蔵庫内で $8 \sim 12$ 時間水戻 したものを 4 分割し，それぞれを家庭用冷蔵庫の冷凍庫 中 $-15^{\circ} \mathrm{C}$ で 1 日， 1 ヶ月， 2 ケ月， 3 ヶ月間凍結保存し た。

\section{(3) 調理方法}

官能検査に用いたマツタケとナメコの調理方法は表 1 に示した通りである。

シイタケについては $1 \%$ 塩分になるように食塩を加え, 戻し汁を加え煮含めた。

\section{（4）官能検査}

検査項目は, 香り (強弱, 良悪), 味 (強弱, 良悪), テクスチャー (良悪), 総合（美味しさ）について 5 段 階評点法で行なった。パネルは料理教室に通う生徒20〜 60 代，平均 30 歳の男女 50 人で行った。

\section{（5）検定}

分散分析とTukey 法による多重比較を用いて行った。

\section{結果·考察}

冷凍したマツタケとナメコの嗜好上の受容性について の官能検査の結果は図 1 に示した通りである。

マツタケについては, ホイル焼き, 汁ともに, いずれ の項目にも有意差はないが，香りの良し悪しは冷凍品が 好まれる傾向にあり，そのことが総合評価に大きく寄与 していると考えられる。

また, マツタケ汁の香り（強弱）は差がないのに対し， 香り（良悪）は冷凍品の方がよいという結果を得た。こ の香りの結果については検討を重ねる必要がある。

ナメコについては, マツタケに比べると冷凍による影 響が少なく, 生鮮品と冷凍品の差が小さい結果を得られ た。

これらの結果より, 冷凍品と生鮮品のキノコの有意な 差がないことから，キノコを冷凍保存することは嗜好上 可能であると考えられる。

一方, 干しシイタケは一度になとめて, 好ましい条 


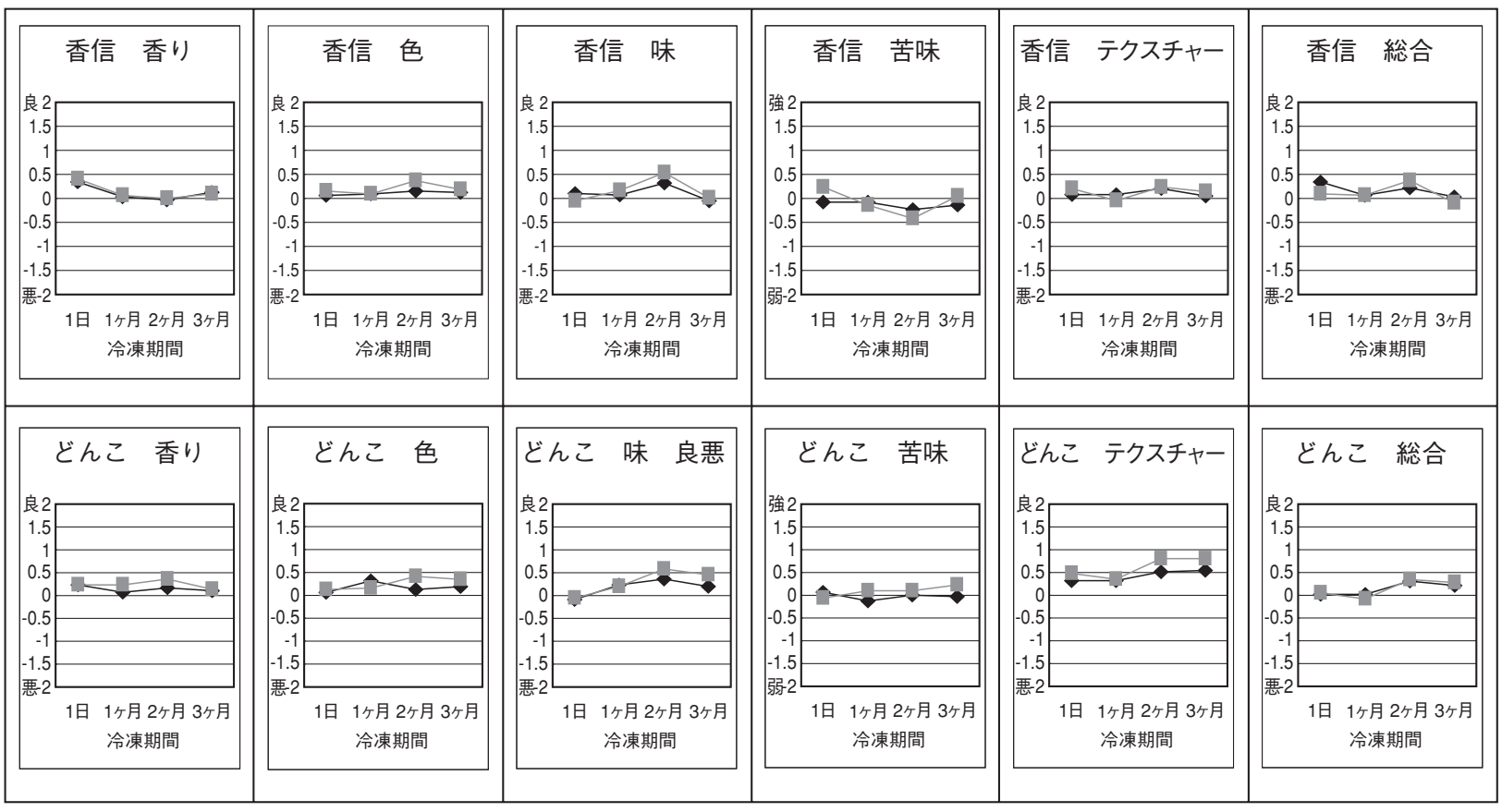

口水戻し後冷凍保存 水戻し1日

図 2 水戻し後冷凍した干しシイタケの官能検査結果

件2)314)5)6)7)8) で水戻し，小分けにした後，1日，1 月月， 2 ヶ月，3 ケ月間冷凍保存し，一晚水戻ししたものを対 照として官能検査に用いた。結果は図 2 に示した。

図に見られるように，水戻しした干しシイタケを 3 ヶ 月位冷凍保存しても両者の間で有意差が認められず，実 用上, 水戻ししたものを冷凍保存しても美味しさには差 し支えないものと考えられる結果が得られた。

なお, 干しシイタケの保存は, 一年程度の冷蔵保存に おいて, 充分その品質が保たれることが実験的に確認報 告8)されている。

\section{まとめ}

生鮮ナメコ，マツタケは，短期間冷凍保存してもその 嗜好性は生鮮品と変わらないことがわかった。干しシイ タケは，好ましい水戻し条件で水戻しした後に小分けし て冷凍保存しても，3 ケ月程度は嗜好性が変わらないこ とを明らかにすることができた。この結果, 調理ごとの 水戻し作業の煩わしさの軽減と, 水戻し時間の省力化に 繋がることが示唆された。

\section{文献}

1）石黒弥生, 菅原龍幸: 冷凍した食用担子菌類の嘫好性
食生活学会誌 $17 \quad$ No. $3 \quad 247 \sim 254$ (2006)

2）菅原龍幸, 松本仲子 : 干しシイタケの調理法に関する調 查 日本食生活文化調査研究報告集: 昭和 58,59 年度助成 対象

3）青柳康夫, 菅原龍幸 : 干し椎茸の水戻しに関する一考察 日食工誌 33 No. 4 244 249（1986）

4）佐々木弘子, 中村尚子, 青柳康夫, 菅原龍幸 : 干し椎茸 の水戻しと加熱調理に抢ける遊離アミノ酸の挙動について 日食工誌 35 No. $2 \quad 299 \sim 297$ (1988)

5）佐々木弘子, 中村尚子, 甲田道子, 松本仲子, 青柳康夫, 菅原龍幸：干し椎茸の水戻し条件について, 日食工誌 36 No.4 293〜301 (1989)

6）佐々木弘子, 酒井登美子, 青柳康夫, 菅原龍幸: 干し椎 茸の水戻し加熱加工に打ける香気生成関連物質の変化 日 食工誌 40 No. 2 107〜112（1993）

7) Sugahara Tatsuyuki:Food Nutritional Study of Mushrooms Annals of the Institute of Nutrition Sciences Kagawa Nutrition University No.9 33 68 (2001)

8) Hiroko Sasaki, Yukiko Negishi, Masami Okuzaki, Tatsuyuki Sugahara; Variation in Tasty Component of Drid Shiitake Mushroom [Lentinus edodes (Berk) Sing.]under the Differet Storage Condition

J.for the Integrated Study Dietary Habits 11 No.3 289 295 (2000) 